\title{
Macbeth in the Higher Education English Language Classroom
}

\author{
Jonathan Sharp
}

\begin{abstract}
This paper presents the latest phase in an ongoing project to develop and widen the scope of drama-based classes in the practical language section of a German university English department. A brief overview of the use of literature in the (English) language classroom is given, with examples of some recent models, before turning to a consideration of practical dramabased approaches in Shakespeare education. This forms the background against which the main report on practice is presented. The Sprachpraxis section of the University of Tübingen English Department is briefly introduced before the focus shifts to the most recent example: a course on Shakespeare's Macbeth involving drama-based methods. Course design, assessment and literature choice are discussed, before the pre- and postcourse expectations and impressions are explored using data gathered from student questionnaires and teacher diary entries. Based on this analysis, initial outcomes are suggested for the continued progress of drama-based elements in the Sprachpraxis curriculum.
\end{abstract}

\section{Introduction: DiE in Sprachpraxis}

Since 2011 the present author has been a senior lecturer in practical academic language skills (Sprachpraxis) at the English Department of the University of Tübingen, Germany. An ongoing interest and commitment within my work has been the development of classes using drama-based approaches in various ways ${ }^{1}$. All of these classes have so far fallen under the departmental category of 'oral communication': courses held exclusively in English, with the purpose of practicing and improving students' spoken language proficiency (for further details see section 3.1 below). Initial evaluation has suggested that classes which investigate and practically explore drama techniques for language learning and teaching are valued and appreciated by students, especially, understandably, those training to be teachers themselves (Sharp 2014). Indeed classes with a thematic focus on drama-in-education are the longest running of the three types

\footnotetext{
${ }^{1}$ For a full discussion of the background, see Sharp 2014.
} 
currently offered in the Sprachpraxis curriculum ('drama-in-education class'). A second class type was offered for the first time in the summer semester 2014, based more on practical performance skills, whose assessment was based on student performances of dramatic scenes taken both from pre-existing plays as well as self-written and improvised pieces ('performance class'). The third class type, launched in the past semester (winter 2014/15) was based on a single piece of literature, in this case Shakespeare's Macbeth, dealt with from a variety of drama-based angles ('Macbeth class'). This class, and its initial outcomes, is the focus of the current paper.

\section{Literature, Language Education and the Bard}

\subsection{Literature and language teaching: background}

The Macbeth class engages with two separate yet interconnected pedagogical approaches to literature - firstly, using literature as material in the language class; secondly, using creative/drama-based methods to explore literature, specifically Shakespeare.

The use of literature in the language classroom is well established. Friederike Klippel and Sabine Doff have discussed literature extensively, in its descriptive, social and expressive functions, as "a central focus of language learning" (Klippel \& Doff 2007: 128). Alan Duff and Alan Maley identify benefits which literature can bring to language teaching: a wide range of "genuine texts"; a "vehicle for culture"; and the involvement of "affect and emotion" (Duff \& Maley 2011: 5f). They suggest an array of practical lesson ideas involving literature, many of them creative, and some recognizably drama-based (Duff \& Maley 2011). The creative element is perhaps the one which distinguishes the use of literature most of all above the more instrumentally-focused course book format: in this vein, Nünning and Surkamp point to the specific potential of literature to provoke "questioning, reaction and the stating of opinion" (Nünning \& Surkamp 2008: 13), with creative approaches working in tandem with more traditional forms of text analysis (Nünning \& Surkamp 2008). Engelbert Thaler developed a model of Literary Communicative Competence (LCC) (Thaler 2008) based on both Communicative Language Teaching (CLT) and Michael Byram's model of Intercultural Communicative Competence (ICC) (Byram 1997). In Thaler's model, 'creating' sits alongside 'reading' and 'understanding' as a key skill engaged when working with literature, constituting six categories of creative response: written, spoken, scenic (drama-based), visual, acoustic and manual (Thaler 2008: 55f). More recently-documented creative work with texts has even broken classroom boundaries leading to more 'large-scale' products (Schewe 2013). An example of this is Stephen Boyd and Manfred Schewe's 'cultural transfer project', involving the creation of an English language

\footnotetext{
2 In the original: „Texte bildeten schon immer einen Mittelpunkt des Sprachenlernens.“ (Klippel Doff 2007: 128).
} 
adaptation of a German-language play, culminating in a full production (Boyd \& Schewe 2012) and including film material of the process.

Thus it seems that creative approaches to literature in the language classroom are both well established and well documented. Klippel \& Doff (2007: 128) however raise a further crucial consideration: "Language and literature lessons can be effectively connected through text work, provided that the texts chosen are suitable for this double purpose." 3

In this regard, particular attention should perhaps be paid to selecting a work by Shakespeare (see also 'class' below).

\subsection{Shakespeare}

Due to the fact that Shakespeare's work remains a staple of many school and university English curricula, and that it is generally regarded by students as 'difficult', there has been inevitable interest in the potential of more enlivening, engaging methods of approaching it for educational purposes. And vice versa: theatre companies such as the Royal Shakespeare Company ${ }^{4}$ (RSC) and Shakespeare's Globe in London ${ }^{5}$ have recognized the importance of educational work to engage with and attract teachers and younger audiences. Both companies are also involved in collaborations with higher education institutions to provide a practical element in post-compulsory educational dealings with Shakespeare. Indeed, this rapidly developing and mutually beneficial dialogue between drama-in-education and professional theatre can be seen as a significant recent trend. A notable upcoming example of this dialogue in action is the RSC's A Midsummer Night's Dream: A Play for the Nation, which will tour the UK in 2016, using amateur companies and schoolchildren as part of the production in each location. ${ }^{6}$

Rex Gibson looms large in any survey of Shakespeare-in-education, however brief. A former schoolteacher, Gibson worked on the 'Shakespeare and Schools Project', based at the Cambridge Institute of Education and offering professional development to teachers in practical methods of approaching Shakespeare (Stredder 2009: 5). This work resulted in the development of the Cambridge School Shakespeare: student-friendly editions of the plays offering ideas and tasks for critical and creative engagement, thematic discussion and performance, while at the same time retaining the full original text ${ }^{7}$. Gibson

\footnotetext{
3 „Sprach- und Literaturunterricht lassen sich in der Textarbeit gut miteinander verbinden, vorausgesetzt, es werden Texte zugrunde gelegt, die geeignet sind, diese Doppelfunktion zu erfüllen“ (Klippel Doff 2007: 128).

${ }^{4}$ See http://www.rsc.org.uk/education/ [last accessed 15 ${ }^{\text {th }}$ May 2015].

5 See http://www. shakespearesglobe.com/education/ [last accessed 15th May 2015].

6 See http://www.rsc.org.uk/explore/projects/a-midsummer-nights-dream-a-playfor-the-nation.aspx [ last accessed 15th May 2015].

7 See http://www. cambridgeschoolshakespeare.com [last accessed 15 ${ }^{\text {th }}$ May 2015].
} 
advocated practical approaches as "the antithesis of methods in which students sit passively, without intellectual or emotional enjoyment" (Gibson 1999: xii), arguing instead that a full engagement with the plays required them to be "completed by enactment of some kind" (ibid. xii). In fact, the combination of 'intellectual and emotional' aspects was key to his project: rather than positing practical methods over and above more standard methodologies, he maintained the potential of active work to "dissolve the traditional opposites of analysis and imagination, intellect and emotion", and aimed instead at the final goal of "informed personal responses" to the plays (ibid. xiii).

James Stredder is one of many Shakespeare educationalists inspired and trained by Rex Gibson at the Cambridge Project discussed above. He emphasizes the range of educational contexts in which Shakespeare is dealt with, and indeed his notion of "the pedagogy of 'Shakespeare shared"' (Stredder 2009: $\mathrm{xvi}$ ) is intended as just as relevant at university as at primary school. He cites "the problem of monumentalism" (ibid. 6) - the tendency to put Shakespeare on a pedestal, thus increasing reluctance to approach him - as a universal educational problem, fuelled principally by fear of the difficulty of the language (ibid. 116). He offers a range of activities and ideas for approaching the specific challenges of the plays, while at the same time pointing out the value of practical methods in creating a healthy general environment in which to learn and develop communication skills (ibid. 11). Working more than a decade after Rex Gibson's initial work at Cambridge, Stredder reflects interest in the simultaneous improvement of 'life skills' of any educational endeavour, parallel to the specifics of the particular discipline. Practical approaches to Shakespeare, he argues, can be "motivating, 'empowering', developing confidence", while not losing sight of perhaps the most obvious advantage, one never to be underestimated: "the pleasure and support of social, creative activity" (ibid. 6).

While most work has concentrated on school education, interest has also increased in practical approaches at post-compulsory levels. Milla Cozart Riggio edited a volume of essays entitled Teaching Shakespeare Through Performance, which offers theoretical and historical contexts as well as examples of practice and resources. The theoretical contributions, as well as many practice reports from higher education, illustrate that there has been significant growing interest in the field in a post-school context (Riggio 1999). This is also reflected at an institutional level. The Capital Centre, based at the University of Warwick and in collaboration with the RSC, began life concentrating on practical methods in the study of Shakespeare ${ }^{8}$, before expanding to include other areas, some within completely separate disciplines. The Shakespeare Institute at the University of Birmingham also works closely with the RSC, offering MA courses with modules involving creative, ensemble-based work; and more recently, a $\mathrm{PhD}$ programme entitled 'Shakespeare and Creativity', incorporating both theatrical

8 See http://www2.warwick.ac.uk/fac/cross_fac/capital/_[last accessed $15^{\text {th }}$ May, 2015]. For a more detailed discussion, see Sharp 2014. 
and academic elements. ${ }^{9}$

Therefore a general trajectory may be identified: from earlier work which perhaps emphasized the instrumental aspects of practical work in understanding and appreciating the plays in a purely educational context (normally school), to a widening of the scope to include other educational levels, including post-compulsory, and the development of more general skills; and more recently to an increased collaboration between professional theatre companies, schools and institutions of higher education.

\section{The Class}

\subsection{Background}

The Sprachpraxis section of the English Department at the University of Tübingen is organized around three core areas: written communication, oral communication and translation ${ }^{10}$. In each of these areas, there are classes at Level I and Level II, depending on degree type and stage of studies. The aim of the Oral Communication II classes is to practice and improve students' spoken English in a variety of formats (presentation, speech, debate, question-andanswer etc.), within an academic context. Topic choice is left to the individual teacher, but should involve something of relevance to either the students' general area of study, and/or to their future careers as teachers. Dramabased classes have been offered since 2011 as part of Oral Communication II courses, starting in winter semester 2011/12 with the drama-in-education class described above. Since the majority of students in the classes are on the teaching degree programme, a focus on educational applications of drama appeared logical, and seemed indeed to be appreciated by the students (Sharp 2014). By the winter semester 2014/15, however, Oral Communication II had been made an obligatory course for students on the Interdisciplinary American Studies programme, which changed the make-up of the typical class group. As a result, of the 23 students starting the Oral Communication II Macbeth class in winter 2014/15, ten were on the teaching programme; ten were on the Interdisciplinary American Studies programme; and three were on the English Studies BA programme.

I decided to base the class on a piece of literature to reflect this new balance, as literature in some shape or form is read and worked on in classes within all the degree programmes offered at the department, as well as being of special relevance to those on the teaching degree. Additionally, a full production of Macbeth was planned for May 2015, to be performed at the theatre in the Brechtbau, which houses the English Department. Although there was

\footnotetext{
9 See http://www.birmingham.ac.uk/schools/edacs/departments/shakespeare/index. aspx [ last accessed 15th May, 2015].

${ }^{10}$ For further information on the University of Tübingen English Department see Sharp 2014.
} 
no obligation for students in the class to get involved in the production, the connection was made clear in the online course description, and opportunities were offered to attend planning meetings and auditions for the project:

Similar to my other Oral Communication II classes the focus will be on drama. However, this particular class will work on a single play: Shakespeare's Macbeth, which will be the foundation for the group's discussions, presentations, and practical explorations. There is another element: there will be a full production of the play happening in the Brechtbautheater in May/June 2015 as part of the Shakespeare anniversary years of 2014 and 2016. Through the class, by getting to know the play from a practical perspective, there may be opportunities to get involved in a number of different ways in the final production. ${ }^{11}$

In keeping with standard assessment guidelines, students in the class were required to hold a presentation, in groups of three, on some aspect of the play. As in the other drama-based classes, I gave students free choice of topic; but they were provided with some guidelines to help them. They could for instance deal with a particular scene, character or aspect (e.g. the supernatural) from the play. Crucially, however, the emphasis was on creative and subjective responses to the play: no secondary or critical textual material was provided in class, nor permitted to be presented as part of the student-led sessions. Therefore students were encouraged to respond to the text individually:

In terms of how you should present: be CREATIVE! This is a class on a very old text, but I want to encourage you to think of it in original, personal ways. This is your chance to think like actors and directors: never mind the centuries of literary criticism - what is your interpretation? ${ }^{12}$

So while the students were used to dealing with literature in other classes, an intention of this class was to creatively build on the theoretical aspects with which they had perhaps been confronted elsewhere. Similar to my other drama-based classes, the sessions had to involve the class actively, but this time a wider scope was offered than the exclusively educational focus of the drama-in-education class:

The one rule is that the presentation should focus on either practical and/or educational aspects. This means that you should consider either how the scene or character or aspect could/should work on stage or on screen, and/or how it could be dealt with in the classroom (how to teach it). I would encourage you to involve the class in drama activities, but this is not absolutely necessary. However, the class should be actively involved somehow. ${ }^{13}$

\footnotetext{
11 See https://campus.verwaltung. uni-tuebingen.de/lsfserver/rds?state= verpublish\&status=init $\&$ vmfile=no\&publishid=111430\&moduleCall=webInfo\& publishConfFile=webInfo\&publishSubDir=veranstaltung [last accessed 18th March, 2015].

12 See footnote above.

13 See footnote above.
} 
In preparation for the sessions, and to introduce the students to the drama-based techniques with which they might not necessarily be familiar, the opening three weeks of the semester consisted of teacher-led sessions where we explored the play practically:

- Week 1: Mini-workshop on Shakespearean verse; Practical exercises on the Prologue from Romeo and Juliet; 'The Globe Game'14.

- Week 2: Introduction to the 'two traditions' in acting (text-based; emotion-based) (Barton 1984).

- Week 3: Practically contrasting the two approaches from week 2 using a passage from Macbeth.

From week 4 onwards, the class sessions were devoted to student-led sessions until the very last session where we discussed the class and pooled the students' feedback.

\section{Choice of play}

There were various reasons for choosing a play by Shakespeare, and Macbeth specifically. Firstly, as one of the most revered figures in literature, Shakespeare can evoke awe and even fear in students, given his canonic status in both academic and theatrical contexts. For this reason however, it can be even more fun to subvert him, play with him, pull him apart and put him back together in unexpected ways. The contrast of these kinds of approach with his image as the demi-God of English literary culture can yield surprising and satisfying results. Secondly, Shakespeare plays leave significant space for individual interpretation, with their absence of explicit stage directions and character descriptions. "The life of (Shakespeare's) plays is in the language, not alongside it, or underneath it" (Eyre 1993: 176); thus it would seem particularly apt to use Shakespeare in a class whose ultimate aim was language practice through creative individual response to a piece of literature. Thirdly, with Shakespeare still present in the school curricula in the German secondary system, the teaching degree students will have to deal with him in their own classrooms in the future: the class therefore could hopefully provide some new impulses in how to do so.

The reasons for choosing Macbeth were practical and thematic. Since many students read the play as one of the most typically dealt-with of Shakespeare's

\footnotetext{
${ }^{14}$ An exercise I designed in which the group sits in a large circle on the ground while a student performs a speech standing in the middle. The audience are free to openly encourage or criticize the actor; the actor must deal with whatever reactions they encounter. This is meant to approximate the experience of an actor at the original Globe theatre, surrounded by the baying groundlings!
} 
works in school, they very often come away with not altogether positive impressions, having either been put off by the difficulty of the language, or else having relied on received interpretations in order to pass exams. Again, however, I recognized an opportunity to deal with a text that perhaps was not entirely unfamiliar to the students, and one for which there might even exist some preconceptions, which we could examine creatively and, if necessary, critically. Macbeth is also, compared to the other great tragedies of Hamlet and King Lear, for example, considerably shorter: meaning that more time can be spent on going into textual and dramatic detail compared to simply wading through the text for pure comprehension. Particularly apt for an advanced language class is Shakespeare's inventiveness and creativity, making full use as he does of "the complex linguistic inheritance of English at the time of his mother-tongue's richest expansion" (Bate 2009: 15). This of course is true of all of his works, but as with many other of his major plays, it is possible to detect in Macbeth what Frank Kermode refers to as the "matrices of the language" (Kermode 2000: 215) - key words which recur throughout the play and embody the main thematic concerns. In Macbeth these include "time", "man", "blood" and "darkness" (ibid.). Indeed, during the semester, these words and themes frequently emerged, in presentations which otherwise differed in approach and aim. This link between language and theme meant that language analysis was never far away during our investigations. Finally, a major concern of Macbeth is the rhetorical technique of equivocation - the use of deliberately misleading language in order to avoid telling an awkward truth directly. Linked to the torture of prisoners in the aftermath of the Gunpowder Plot of 1606, it is represented throughout the play, and mostly by the witches, who lead Macbeth into false security by never answering his questions directly, but nevertheless avoiding straight lying (cf. ibid. 201ff). Since this theme is particularly closely linked to language use itself, it provides another apt link between this piece of major literature and the linguistic analysis of benefit to such a class.

\section{Pre-course questionnaire}

In the first session, a questionnaire was provided to the 23 students in the course, intended to gauge general attitudes to drama and Shakespeare:

- Do you like Shakespeare? Why/not?

- What experience, if any, have you had of practical drama before?

- What are your expectations of the class?

- How do you feel about a drama-based class as part of the Sprachpraxis syllabus?

It emerged that all but three of the students had had some exposure to Shakespeare at university level (20 out of 23 ); all had experienced his work to 
some extent in school. Reactions to Shakespeare were very mixed; the most common complaint was that the language of the plays is difficult to understand (9 out of 23). 13 students had had previous experience of practical drama, of which three included post-school experience, while ten had no experience whatsoever. The top answers regarding expectations of the class were to get to know more about Shakespeare and /or Macbeth (9 out of 23); to improve practical language skills ( 8 out of 23); to be creative and/or experience new perspectives (7 out of 23); and to have fun (5 out of 23). The answers for number four were extremely varied, but all were positive. The most frequently occurring notion was that the class was different from other such oral classes on offer.

The amount of pre-experience of Shakespeare was encouraging, as it meant that no-one would be confronting the difficulties for the very first time. The fact that almost half the class had had no previous experience of practical drama was not concerning, as the drama-in-education class had already been functioning well with the same general mix of experience level. It was interesting to note that virtually an equal number of the participants had expectations of the class in the areas of literary understanding/appreciation and language improvement, and encouraging that a significant number were looking forward to the creative and fun elements of the approach.

\subsection{Teacher expectations}

From my perspective, I was looking forward to experiencing an approach different to the drama-in-education class, with a particular emphasis on literature. From the outset, my intention was to engage with the play using drama-based and other creative methods, but still with the principal aim of language practice; given the fact that all of the students in the class also take many courses in literature anyway, I didn't have high expectations that the class would necessarily offer any additional insights into the play as a piece of literature. One other concern was that the class, with its emphasis on collaborative, creative investigation, would still allow enough space for individual reactions and contributions.

\subsection{Student-led sessions}

Students were given free choice in the topic of their session, contingent on certain guidelines (see section 3.1). Time was allocated in the opening weeks to discuss and work on ideas in order to formulate a focused aim. Sessions were held in groups of three or four.

The final session topics were:

- Hearing Shakespeare: the aural effects of Macbeth

- Lady Macbeth in the secondary school classroom 
- Casting the play: visual character concepts

- The witches: staging the supernatural

- Macbeth on film: three recent versions

- Macbeth and the Method actor: 'finding' the characters

- The language of Macbeth: traditional and modernizing approaches

- Macbeth on trial: Who really killed King Duncan?

The topics were wide-ranging, but all focused on practical performance issues, with the exception of the session on dealing with the character of Lady Macbeth in school. All sessions were led by the presenters' own creative opinions on and impulses towards their respective topic.

\section{Post-course impressions}

\subsection{Post-course questionnaire}

In the final session, a questionnaire was provided to the students asking the following questions:

- How effective did you find this class for practice of your spoken English?

- How, if at all, did this class affect your understanding and/or enjoyment of Macbeth as a piece of literature?

- Comment on the class in terms of a) collaboration with the other students; and b) space for individual ideas and contributions.

- Were your expectations of the class met?

Nineteen students completed the questionnaire. As to the first question, the majority reported no particular increased effectiveness in comparison to other oral communication courses (10 out of 19); only five reported that they had found the class "very" effective for practice in spoken English, and four "partially" effective. As to the second question, however, all but one student (18 out of 19) reported that the class had greatly/significantly affected their understanding and/or enjoyment of Macbeth; 10 out of the 19 commented that the class had allowed them the opportunity to view the play from different perspectives; three mentioned the benefits of "creativity/creative approaches". As to number three, all students reported satisfaction with the balance between collaboration within the group and space for individual contribution - but there were no perceivable differences between these categories. Finally, answers to number four varied greatly depending on expectations expressed in the pre-course questionnaire, but were generally positive. 


\subsection{Teacher diary}

Throughout the semester, I kept a diary in which I recorded the work of the class each week and my own personal impressions of it. The potential conflict set up by reflective practitioner research (involving the double role of teacher and researcher) has to be borne in mind. To counter this, as the teacher, I wrote my diary entries immediately after each class session, as a record of my 'gut reaction' to how the class had gone and what I had felt, before I had had too much time to analyse and reflect. Once the semester had finished, I then returned to the diary in its complete form, to see if any trends or patterns had emerged. Looking back, it is striking that throughout the entries the emphasis is on positive responses to the students' creative work, with the major focus being on an understanding of how the play works in practice.

My reactions to the introductory language work were positive, but consistent with previous experiences:

I did the Shakespeare Introductory HO (hand-out), with examples of pentameter etc. At first this always seems boring; I can see some glazed eyes... but then they always warm up once they see the amazing possibilities of mining the text for clues to emotions, relationships, themes, and even staging and blocking. It gets me going too, never fails. It truly is a joy to see how much WS (William Shakespeare) has actually given us, all without descriptions or directions.

In the entries on the student-led sessions, I was consistently impressed by the standard of the creative ideas and exercises involved. In the session on aural effects, the group brought in sound props for the class to use:

... from bunches of cutlery to rolled up paper, to pots and pans, to a splendid bunch of rusted, Gothic keys. The result was extraordinary. The class sat on the ground with eyes closed as each scene was played out with sound. It was somehow different from the safe distance afforded by radio, and the eyes shut did lend a more threatening tone to proceedings. You felt alone, and you felt the nearness of each sound [...] Lots of wonderful ideas [...] An example was simply a glass dragged, rim-down, across a desk - an eerie, disjointed scraping sound which I couldn't place, as an accompaniment to the witches coven. The class rose very well to the task.

The group who led the session on staging the supernatural asked the question of how to make the witches real, but avoid comic effect, in an attempt to transpose the very serious fear of the supernatural which would have existed in Shakespeare's day to our present context:

The group presented prompt sheets with ways to portray the witches; each group then had to rehearse and present Ii (Act I Scene i) in their style, and discuss it. We had a group of accelerated flower-power hippies, who freaked us all out through their sheer madness; a 'bad-ass' group of hard rockers who you wouldn't want to cross, in a very physical sense; a 
group of schoolgirls, who got us scared through their breaking of normal conventions (parallels were drawn with the kid in the Shining, and how weird it is that 'innocents' can actually be the scariest thing of all, by subverting what we normally expect); and then 3 soldiers, ram-rod straight, staring out front, who kept parroting 'Sir!' after every single line - at first comic, but very soon became unsettling due to the forced artificiality of it all; finally a group enacting some kind of teenage ritual in the forest very Blair Witch, or even a modern Crucible. Forbidden spells being cast in secret.

In the most acting-based of all the sessions, the class was split into those portraying Macbeth and Lady Macbeth, then each student was assigned a piece of text:

This was an original text passage, which we then had to express as a sub-text or 'thought behind the words'. The Macbeths then sat on chairs in the class, eyes closed. The various Lady M's gathered outside, and had to pick a subtext line at random, written by one of the other Lady M's. Having done so, the Lady M's entered the room, and, one-by-one, whispered their line into the ear of every single Macbeth. Then the whole process was repeated the other way round. The effect was stunning: robbed of sight, we again had to rely on our hearing, but this time in a much more psychological way. The words we were hearing were not Shakespeare's, but the emotions behind them, in the solemn atmosphere of the darkened room, were immediately heightened. Comments were made that it was as if you were having these thoughts yourself; the effect of the comments being repeated all round the room functioned like an echo, or a recurring dream. I found myself lingering on some more than others, listening out for them again and again in the room, as if plagued by my conscience. A wonderful exercise, one to remember, and the class dealt with the complexity maturely and gamely.

Of particular note were the entries which recorded moments in which creative exploration during a session led to a direct confrontation with a specific textual or thematic crux. An example is from the session on visual character concepts. Students were asked to draw their concepts of various characters on posters which were then pinned around the classroom and discussed much like pictures at an exhibition:

Some really great stuff came up - like a before and after Macbeth, who had shrunk, withered and aged after becoming king: the physical effects of the moral descent. When I mentioned the text passage about the robes of kingship swamping him ${ }^{15}$, thus physically mirroring his unsuitability and illegitimacy, they were surprised - they hadn't been aware of it! A lovely example of the most creative, human response - corrupted power physically diminishing a person - being, unknown to the students in this case, reflected in the text itself.

\footnotetext{
${ }^{15}$ Macbeth, Act V Scene ii, lines 20-22.
} 
A second similar example comes from the very last session, in which the presenters took on roles as judges in a trial in which Macbeth, Lady Macbeth and the witches were on the stand in order to discern who, ultimately, should bear responsibility for Duncan's murder. Defence councils were formed for each of the accused, and another creative breakthrough was made:

The witch group caught on to the notion of equivocation, again without actually using that word, or being aware of the critical tradition within Shakespearean scholarship on the play (cf. Class 7 on Macbeth's robes). They claimed, rightly, not to have ever told Macbeth to kill Duncan, nor directly that his actions would be ultimately successful.

Thus again, through the creative context of the mock court-case, the witches' legal representatives stumbled naturally across their strongest defence simultaneously a key thematic and linguistic element in the play.

The teacher diary entries therefore seem to reflect overwhelmingly positive impressions of the students' performances, and thematically, the benefit of the approach to a specifically creative engagement with the text as a piece of dramatic art.

\section{Trends and future possibilities}

The Macbeth class represented an attempt to widen the focus of drama-based oral communication classes at Tübingen. The gathering of data in the form of pre- and post-course student questionnaires and a teacher diary was intended to generate initial impressions of the class format; clearly, given the small sample size, no firm conclusions can be drawn at this early stage. However the results did suggest some interesting trends in this testing of the waters. Given the student feedback, it seems that no particular advantage was gained regarding the language practice component of the class. On the other hand, there were surprising results regarding literary aspects. This trend is supported by the post-course questionnaire as well as the teacher diary, which point towards the success of the creative approach in engaging with the play as literature; in responding to it creatively and from various angles; and even in mirroring the themes of the play and also technical and linguistic aspects of the text itself. However the ultimate raison d'être of the class - the practice and improvement of spoken English - was arguably not actually compromised, as the enthusiastic and active response of the students to the play stimulated extensive oral communication in various forms - role-play, presentation, individual feedback, courtroom-style debate, as well as discussion in smaller groups and the class as a whole.

It would seem then that Sprachpraxis classes based on practical drama, in combination with specific plays, can generate positive, creative spaces in which language work with a more literary focus can take place. In this vein, a possible further avenue of practice might be direct collaborative work between Sprachpraxis classes and literature seminars. 


\section{Bibliography}

Barton, John (1984): Playing Shakespeare. London: Methuen

Bate, Jonathan (2009): Introduction to Bate, Jonathan \& Rasmussen, Eric (eds.) Shakespeare, William: Macbeth. Basingstoke: Macmillan

Boyd, Stephen \& Schewe, Manfred (2012): Welttheater: übersetzen, adaptieren, inszenieren. Thomas Hürlimanns Das Einsiedler Welttheater; nach Calderón de la Barca und in englischsprachiger Fassung: Cork's World Theatre. Berlin: Schibri

Byram, Michael (1997): Teaching and Assessing Intercultural Communicative Competence. Clevedon: Multilingual Matters

Duff, Alan \& Maley, Alan (2011): Literature. Oxford: Oxford University Press

Eyre, Richard (1993): Utopia and Other Places. London: Bloomsbury

Gibson, Rex (1999): Teaching Shakespeare. Cambridge: Cambridge University Press

Kermode, Frank (2000): Shakespeare's Language. London: Penguin

Klippel, Friederike \& Doff, Sabine (2007): Englisch Didktik. Berlin: Cornelsen

Nünning, Ansgar \& Surkamp, Carola (2008): Englische Literatur unterrichten

1: Grundlagen und Methoden. Seelze-Velber: Kallmeyer/Klett

Riggio, Milla Cozart (1999): Teaching Shakespeare Through Performance. The Modern Language Association of America

Schewe, Manfred (2013): Taking stock and looking ahead: Drama Pedagogy as a Gateway to a Performative Teaching and Learning Culture. In: Scenario $\mathrm{VII} / 1,5-28$

Shakespeare, William (ed. Kenneth Muir) (2013): Macbeth. London: Arden/Bloomsbury

Sharp, Jonathan (2014): Drama in Sprachpraxis at a German University English Department: Practical Solutions to Pedagogical Challenges. In: Scenario VIII/1, 19-36

Stredder, James (2009): The North Face of Shakespeare. Cambridge:

Cambridge University Press

Thaler, Engelbert (2008): Teaching English Literature. Paderborn: Ferdinand Schöningh

The Shakespeare Institute [http://www.birmingham.ac.uk/schools/edacs/ departments/shakespeare/index.aspx, last access 15

Cambridge School Shakespeare Online

[http://www.cambridgeschoolshakespeare.com, last access 15 th May 2015]

Royal Shakespeare Company [http://www.rsc.org.uk, last access 15 2015]

Shakespeare's Globe [http://www. shakespearesglobe.com, last access $15^{\text {th }}$ May 2015] 
The CAPITAL Centre: Creativity and Performance in Teaching and Learning [www2.warwick.ac.uk/fac/cross_fac/capital/, last access 15 Internet links 